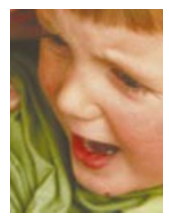

On trial

Dismay greets plans

to test smallpox

vaccine on children

p110

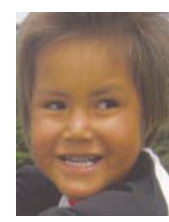

Local uprising

Amerindians angry

over use of blood

samples in studies

p111

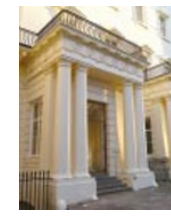

Weapon control

Royal Society backs code of conduct for biowarfare research p112

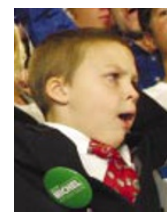

Election blues

Scientists fret as

Republicans

celebrate

p113

\title{
Microbe hunt raises doubts over local benefits of bioprospecting
}

\section{David Cyranoski, Tokyo}

Controversy is likely to follow an international consortium of scientists - including researchers from the Chinese Academy of Sciences - as it embarks on a search for commercially useful microbes in the politically contested areas of Tibet and Inner Mongolia.

The scientists will be on the lookout for previously unknown extremophiles microorganisms that live in inhospitable environments such as salt lakes and hot springs. But it is unclear if the two regions that are made.

The project is being led by microbiologist Bill Grant from the University of Leicester, UK, and includes scientists from the University of Seville in Spain, and the Netherlands branch of the US genomics company Genencor. Its main sponsor is the European Commission, which has donated 1 million euros (US\$1 million). The University of the Western Cape in Cape Town, South Africa, will bring its own funding to the consortium. DNA on site directly from the soil. They will sequence the DNA and search DNA databases for sequences encoding enzymes that give the microbes their special characteristics.

Grant and Genencor have already shown involved will benefit from any discoveries

The researchers will isolate microbial

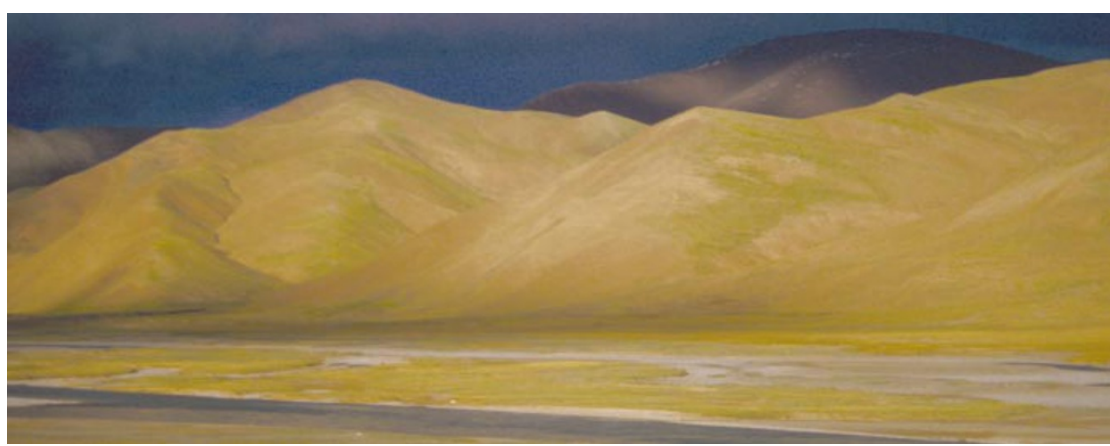

An international consortium is seeking potentially valuable microbes in the harsh Tibetan landscape. that the strategy can be commercially successful. A collaborative expedition to Kenya in 1992 found an extremophile in a soda lake that has an enzyme that breaks down cellulose over an unusually wide range of temperatures. In 1998, Genencor exploited this property in a process for stonewashing jeans.

China hopes to gain commercially from the project. Its science ministry has negotiated with the consortium to retain "sovereign rights" to biological resources found and a share in any commercialization, says Yanhe Ma of the Chinese Academy of Sciences Institute of Microbiology in Beijing, a member of the consortium. But there is no indication

\section{Ground-breaking web test gears up}

\section{Geoff Brumfiel, Washington}

Earthquake engineers are eagerly anticipating the first test of a national network of seismic experiments. The George E. Brown Jr Network for Earthquake Engineering Simulation (NEES) is an $\$ 82$-million project, sponsored by the National Science Foundation, to build a series of 16 centrifuges, shake tables and other large-scale experimental equipment at universities across the United States.

When they are completely integrated in 2004, these earthquake simulators will be part of a network of experiments and software tools that will enable engineers to conduct their research through the web. The first test of the web-interface technology takes place this week at the University of Nevada in Reno. A shake table will vibrate a model bridge fitted with about 100 sensors. These sensors will stream video and data straight into the computers of watching engineers, who will then attempt to analyse the bridge's performance.

"This is the first public peek at this infrastructure," says Dan Reed, director of the National Center for Supercomputing Applications at the University of Illinois at Urbana-Champaign, who oversees the computing aspects of NEES. so far that a fair share of the benefits will filter back to Tibet and Inner Mongolia contentious "autonomous regions" of China - or even that the issue has been discussed. China's autonomous regions are supposed to retain a degree of control over local economic interests, but many commentators argue that Beijing has neglected these rights.

The United Nations' Convention on Biological Diversity, which the European Commission and China signed in 1992, aims to ensure that countries, particularly indigenous and local communities, benefit fairly if their biodiversity proves to be commercially valuable. Ma says that local governments will be helping them with the project, but he gives no details of any plans to bring work or other benefits to the local people.

Huanming Yang, director of the Beijing Genomics Institute and an advocate of the protection of China's genetic resources, says that scientists from local communities should be involved. Chinese researchers should be sensitive to such issues, he says, but foreign researchers should also bear responsibility. John Ackerly, president of the Washingtonbased human-rights group International Campaign for Tibet, agrees. "It's the responsibility of the European researchers to make sure that Tibetans are engaged and given benefits, because Beijing won't do it," he says.

But this is not an easy task. "How could an outsider possibly go about pushing the issue of regional recognition?" asks consortium member Don Cowan of the University of the Western Cape. 